Acta Agriculturae Serbica, Vol. XX, 39 (2015); 29 - 39

UDC 582.475-15(497.11)

COBISS.SR-ID: 219339532

Original research paper

Acta Agriculturae Serbica, Vol. XX, 39 (2015), 29-39

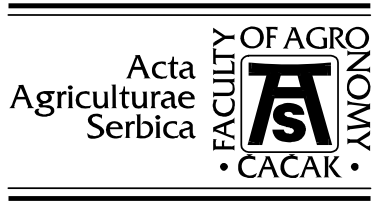

\title{
Height curve as a new aspect of black pine (Pinus nigra) plantations in the Šumadija region
}

\author{
Severin Šikanja \\ University of Singidunum \\ Futura Faculty of Applied Ecology
}

\begin{abstract}
Both ecological aspects i.e. biotic and biotic factors were analyzed and studied in black pine plantations in the Šumadija region. The black pine plantations analyzed within 5 experimental fields are 30, 40 and 55-60 years old, and are found in:

1) good quality habitats

2) medium quality habitats and

3) low quality habitats.

The same-aged plantations were studied in different habitats.

All dendrometric measurements were performed, including diameter, height and tree volume, along with tree analysis and complete growth calculation. Stand structure, thickness, height, structure by basal area and volume structure are also presented.

Height growth proved to be a new significant indicator. Conclusions were drawn, and tending practices for each experimental field and growing recommendations were suggested.
\end{abstract}

Key words: black pine, plantations, Šumadija, height growth.

Received: 15 December 2014 / Accepted: 18 July 2015 
Acta Agriculturae Serbica, Vol. XX, 39 (2015); 29 - 39

\section{Introduction}

Black pine plantations are widespread in Serbia under diverse natural conditions, not only in terms of geographical, orographic and climatic factors, but also in relation to the geological base, soil types and plant communities. (Jovanovic 1988). Black pine plantations are found on limestone, dolomite, serpentinite and siliceous rocks, which certainly affected their composition and structure, individual floral elements and the stand since black pine plantations are of great importance for forestry theory and practice in FMP (Antic, Jovic, Avdalovic, 1988.) However, a significant proportion of black pine plantations are located in habitats where the ecological value exceeds the environmental requirements of pine.

In other words, the black pine is found in the terrain where utilization of all land potentials is not possible (Tomanić 1968).

The total surface area of black pine plantations in Serbia is 65,200 ha, which is a rather large coverage, considering the presence of only one type. The total black pine wood volume is $3,099.385 \mathrm{~m} 3$, which represents a huge potential in both forest environmental and economic terms. The current pine increment over 10 years is $1,435.154 \mathrm{~m} 3$. All these data deserve attention and offer hope, but on the other hand, they put on a great obligation imposed by the Forestry Sciences (Invetura a National Forest, 2012).

An elevation curve is characteristic of and important for height increment of a stand. During the life of the stand it shifts to the right (Stamenkovic, 1988). In this study, importance is given to height curves in black pine plantations. Height curves are essential and important indicators of stand development and increment (Assmann, 1966). Altitude curves are obtained by measuring the height of a number of trees, taking every diameter (which depends on the stand situation), calculating the average height $\mathrm{Hs}$ and noting it on the $\mathrm{Y}$-axis, and the $\mathrm{X}$-axis diameter gear. The same procedure applies to each diameter degree, and then the dots are joined. Such fault lines are called a height curve (Mirković, 1972). Altitude curves are used in this paper to evaluate pine tree development and growth.

\section{The aim and task of the paper:}

1. Identify the characteristics of an internal stand structure of the black pine in a specific area: diameter, bulk, height structure and the structure by the root, and present the height curve. (Height curve and height increment are important new parameters used to determine the black pine situation in different habitats). 
Acta Agriculturae Serbica, Vol. XX, 39 (2015); 29 - 39

2. Study the development and growth of individual trees and their impact on plantation development, focusing on the impact of tree position in the stand on the dynamics of black pine plantations and duration of the production process.

3. Determine the most appropriate care measures as a priority, based on the research results on black pine plantations, and if possible to determine the optimal duration of the production process.

4. Compare and analyze the plantations of black pine stands of Hungarian oak and Turkey oak (as indigenous vegetation in this area), and evaluate the comprehensive justification or even introduction of black pine in these habitats.

\section{Materials and methods}

The research area is the Woodland of Kragujevac, including the Forestry Management of Gornji Milanovac and Kragujevac. The actual measurements in black pine plantations were conducted in the area covered by the GružanskoLepenička-Jaseničke Forests Management Unit within the Forest Administration Kragujevac.

The Gružansko-Lepenica Forest Management Unit covers an area of 2,949 ha, with 275 ha under forest plantations, accounting for $10 \%$ of the total area. Noteworthy, these are black pine plantations only, with no presence of other species.

The experiment was carried out according to the scientific research methodology (Banković 2003) by allocation of experimental fields, measuring the pelvic diameters of all trees, with the instrument, the swing calipers, two crosswise, then the arithmetic backgrounds were calculated. Tree height was measured with a Blume-Leis altimeter in order to obtain access to the height of the curve. In each instance, in all experimental fields, diameter samples were obtained by a Pressler drill for increment calculation. Based on the data, tree volume in all experimental fields was calculated. Also, soil profiles from all experimental fields were excavated for detailed analysis of the land, in order to study black pine plantations of different age and on different soil types. 
Acta Agriculturae Serbica, Vol. XX, 39 (2015); 29 - 39

\section{Environmental factors in the study areas:}

Environmental factors include abiotic and biotic factors, and they seem to be complex and constant, and they influence black pine plantations in the study area. Biotic factors are all living things, such as plants and animals (Myers 2002).

Abiotic factors include the relief (orographic factors), climate, soil (edaphic factors). Certainly, the influence of man must not be neglected; these are the socalled anthropogenic factors (Cedro 2006).

In order to study the floristic composition and phytosociological determination of the origin of the stands, phytocoenological capture in all sample plots was obtained by the Braun-Blanquet method (Tomić, 2004). Thermophilic deciduous forests of Hungarian oak and Turkey oak, belonging to this connection, form the zonal vegetation in most parts of Southeastern Europe, affecting mainly the whole Moesian province of Serbia, Macedonia, Bulgaria, Romania and southern parts of eastern Bosnia and northern Greece. The community in this connection occupies lower and hilly parts up to $600 \mathrm{~m}$ above sea level, plateaus and gentle slopes outside the influence of additional humidity from river valley (Rakonjac et al. 2000).

\section{Results and Discussion}

Graph 1 showing height curves of the five experimental fields reveals the following:

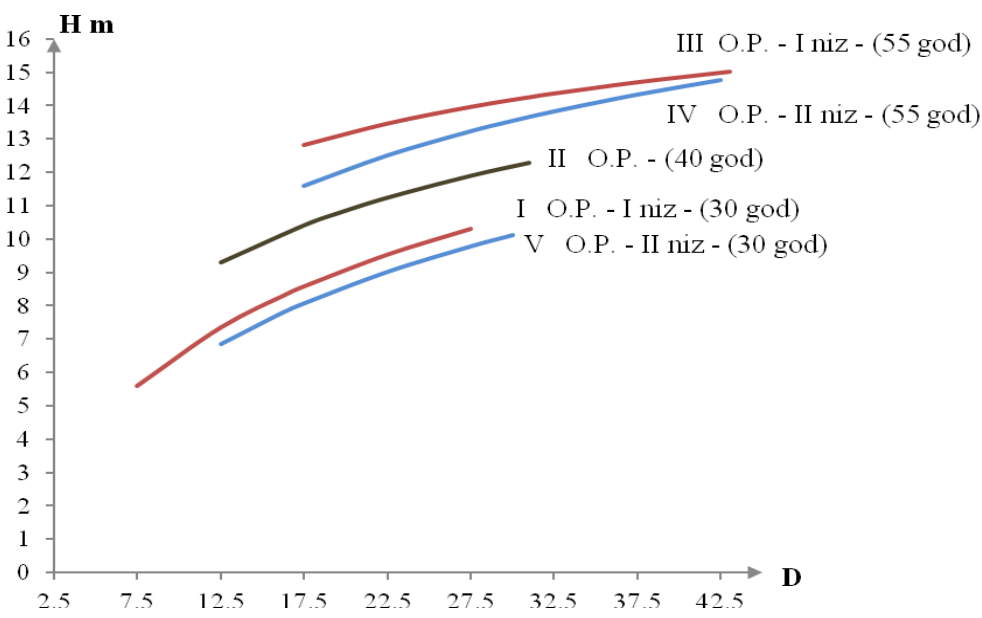

Graph 1: Height curves of the five experimental fields 
Acta Agriculturae Serbica, Vol. XX, 39 (2015); 29 - 39

a) The red altitude curve, labeled III experimental field I series, is the height curve for black pine plantations 55 years of age. The blue vertical drop curve below is marked as IV experimental field II series of the same age as the upper curve. Altitude curve values are larger than those for black pine plantations in better habitats.

b) Similarly for young crops in the same chart, marked with the red altitude curve, the experimental field and a string underneath the blue altitude curve, marked as experimental field V, series II, both plantations are 30 years of age. The red curve is above the blue one. Experimental fields III and I are on a eutric brown soil, the most productive in this study, whereas experimental fields IV and $\mathrm{V}$ are on a poor shallow humus siliceous soil. Obviously, the black pine recognized better habitat and soil conditions, which gave the altitude curve as a very important result.

This is a very important indicator for black pine plantations in this area, because altitude curves are indicators of internal stand construction. Moreover, based on the measurement of all taxation elements of the experimental fields, the consequences of untimely and inadequate care practices are clearly visible, such as reduced overall growth, reduced general plantation condition, reduced vitality and increased sensitivity to the damaging effect of winds and avalanche.

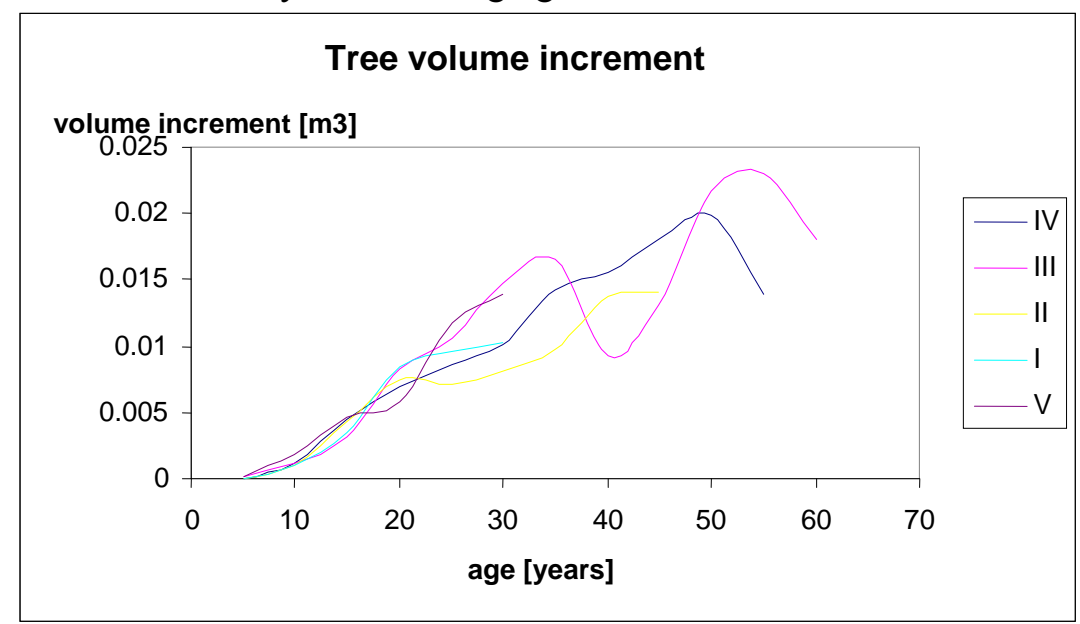

Graph 2: The graph shows a decline in growth after the first culmination of the height increment. The reason for this is untimely tending. The following tables show two different cases - plantations with and without care practices. 
Table 1. Black pine plantations on the best land - with care practices

\begin{tabular}{|c|c|c|c|c|c|c|c|c|c|c|c|c|c|c|c|c|c|c|}
\hline \multirow{3}{*}{$\begin{array}{c}\text { diameter } \\
\text { degree }\end{array}$} & \multicolumn{6}{|c|}{ INITIAL STATE } & \multicolumn{6}{|c|}{ FUTURE TREES } & \multicolumn{6}{|c|}{ FOR CUTTING } \\
\hline & \multicolumn{2}{|c|}{$\mathrm{N}$} & \multicolumn{2}{|c|}{$\mathrm{G}$} & \multicolumn{2}{|c|}{$\mathrm{V}$} & \multicolumn{2}{|c|}{$\mathrm{N}$} & \multicolumn{2}{|c|}{$\mathrm{G}$} & \multicolumn{2}{|c|}{$\mathrm{V}$} & \multicolumn{2}{|c|}{$\mathrm{N}$} & \multicolumn{2}{|c|}{$\mathrm{G}$} & \multicolumn{2}{|c|}{$\mathrm{V}$} \\
\hline & $\begin{array}{l}\text { By } \\
\text { ha }\end{array}$ & $\%$ & $\begin{array}{l}\text { By } \\
\text { ha }\end{array}$ & $\%$ & By ha & $\%$ & $\begin{array}{l}\text { By } \\
\text { ha }\end{array}$ & $\%$ & $\begin{array}{l}\text { By } \\
\text { ha }\end{array}$ & $\%$ & By ha & $\%$ & $\begin{array}{l}\text { By } \\
\text { ha }\end{array}$ & $\%$ & $\begin{array}{l}\text { By } \\
\text { ha }\end{array}$ & $\%$ & $\begin{array}{l}\text { By } \\
\text { ha }\end{array}$ & $\%$ \\
\hline 7.5 & 1 & 1 & 1 & 1 & 1 & 1 & 1 & 1 & 1 & 1 & 1 & 1 & 1 & 1 & 1 & 1 & 1 & 1 \\
\hline 12.5 & 1 & & 1 & 1 & 1 & 1 & & 1 & 1 & & 1 & 1 & 1 & 1 & 1 & 1 & 1 & 1 \\
\hline 17.5 & 12 & 3.66 & 0.288 & 1.27 & 3.88 & 1.26 & 4 & 3,49 & 0,1 & 1.11 & 1.28 & 1.08 & 4 & 4 & 0.09 & 1.35 & 1.2 & 1.22 \\
\hline 22.5 & 16 & 4.88 & 0.63 & 2.76 & 8.38 & 2.79 & 8 & 6.89 & 0.32 & 3.56 & 4.2 & 3.55 & 4 & 4 & 0.15 & 2.25 & 2.08 & 2.11 \\
\hline 27.5 & 144 & 43.9 & 8.55 & 37.45 & 112.27 & 37.39 & 16 & 13.8 & 0.95 & 10.57 & 12.53 & 10.6 & 56 & 56 & 3.32 & 49.92 & 43.85 & 44.47 \\
\hline 32.5 & 140 & 42.68 & 11.61 & 50.85 & 152.6 & 50.82 & 76 & 65.51 & 6.3 & 70.07 & 82.84 & 70.05 & 32 & 32 & 2.65 & 39.84 & 34.88 & 35.37 \\
\hline 37.5 & 16 & 4.88 & 1.76 & 7.67 & 23.2 & 7.74 & 12 & 10.31 & 1.32 & 14.69 & 17.4 & 14.72 & 4 & 4 & 0.44 & 6.64 & 15.8 & 16.83 \\
\hline 42.5 & 1 & 1 & 1 & 1 & 1 & 1 & 1 & 1 & 1 & 1 & 1 & 1 & 1 & 1 & 1 & 1 & 1 & 1 \\
\hline \multirow[t]{10}{*}{ TOTAL } & 328 & 100 & 22.83 & 100 & 300.25 & 100 & 116 & 100 & 8.99 & 100 & 118.25 & 100 & 100 & 100 & 6.65 & 100 & 97.81 & 100 \\
\hline & \multicolumn{6}{|c|}{$\mathrm{Dg}=31.1 \mathrm{~cm}$} & \multicolumn{6}{|c|}{$\mathrm{Dg}=31.4 \mathrm{~cm}$} & \multicolumn{6}{|c|}{$\mathrm{Dg}=29.15 \mathrm{~cm}$} \\
\hline & \multicolumn{6}{|c|}{$\mathrm{Hg}=18.7 \mathrm{~m}$} & \multicolumn{6}{|c|}{$\mathrm{Hg}=18.9 \mathrm{~m}$} & \multicolumn{6}{|c|}{$\mathrm{Hg}=14.8 \mathrm{~m}$} \\
\hline & \multicolumn{6}{|c|}{$\mathrm{Iv}=3.87 / \mathrm{ha}$} & \multicolumn{6}{|c|}{$\mathrm{I} \mathrm{v}=1.12 \mathrm{~m} 3 / \mathrm{ha}$} & \multicolumn{6}{|c|}{$\mathrm{Iv}=0.9 \mathrm{~m} 3 / \mathrm{ha}$} \\
\hline & \multicolumn{6}{|c|}{ Piv $=0.63 \%$} & \multicolumn{6}{|c|}{$\mathrm{Piv}=1.23 \%$} & \multicolumn{6}{|c|}{ Piv $=2.04$} \\
\hline & \multicolumn{6}{|c|}{ STAND AGE } & \multicolumn{6}{|c|}{ Participation FUTURE TREES } & \multicolumn{6}{|c|}{ INTENSITY CUTS } \\
\hline & & & 55 & EARS & & & & & By & $=35.36$ & & & & & By & $=30.48$ & & \\
\hline & & $\mathrm{ST} A$ & TUS AI & TER CL & TTING & & & & By & $=39.37$ & & & & & $\mathrm{By} C$ & $=29.12$ & & \\
\hline & & 228 & 16 & & 201.64 & & & & By & $=39.38$ & & & & & By & $=32.84$ & & \\
\hline & & & & & & & & & By $\mathrm{P}$ & $=36.58$ & & & & & By $\mathrm{P}$ & $=31.35$ & & \\
\hline
\end{tabular}


Table 2. Black pine plantations on the worst land - without care practices

\begin{tabular}{|c|c|c|c|c|c|c|c|c|c|c|c|c|c|c|c|c|c|c|}
\hline \multirow{3}{*}{$\begin{array}{c}\text { diameter } \\
\text { degree }\end{array}$} & \multicolumn{6}{|c|}{ INITIAL STATE } & \multicolumn{6}{|c|}{ FUTURE TREES } & \multicolumn{6}{|c|}{ FOR CUTTING } \\
\hline & \multicolumn{2}{|c|}{$\mathrm{N}$} & \multicolumn{2}{|c|}{ G } & \multicolumn{2}{|c|}{$\mathrm{V}$} & \multicolumn{2}{|c|}{$\mathrm{N}$} & \multicolumn{2}{|c|}{ G } & \multicolumn{2}{|c|}{$\mathrm{V}$} & \multicolumn{2}{|c|}{$\mathrm{N}$} & \multicolumn{2}{|c|}{ G } & \multicolumn{2}{|c|}{$\mathrm{V}$} \\
\hline & $\begin{array}{l}\text { By } \\
\text { ha }\end{array}$ & $\%$ & $\begin{array}{l}\text { By } \\
\text { ha }\end{array}$ & $\%$ & By ha & $\%$ & $\begin{array}{l}\text { By } \\
\text { ha }\end{array}$ & $\%$ & $\begin{array}{l}\text { By } \\
\text { ha }\end{array}$ & $\%$ & By ha & $\%$ & $\begin{array}{l}\text { By } \\
\text { ha }\end{array}$ & $\%$ & $\begin{array}{l}\text { By } \\
\text { ha }\end{array}$ & $\%$ & By ha & $\%$ \\
\hline 7.5 & I & / & 1 & & I & I & 1 & 1 & I & 1 & 1 & 1 & l & 1 & 1 & 1 & / & / \\
\hline 12.5 & 61 & 19.48 & 0.74 & 9.08 & 6.18 & 8.77 & 8 & 6.06 & 0.1 & 2.25 & 0.82 & 2.21 & 32 & 27.58 & 0.39 & 14.55 & 3.3 & 14.78 \\
\hline 17.5 & 157 & 50.65 & 3.75 & 46.01 & 31.2 & 44.3 & 52 & 39.39 & 1.25 & 28.08 & 10.4 & 28.1 & 72 & 62.06 & 1.73 & 64.55 & 14.4 & 64.51 \\
\hline 22.5 & 77 & 24.67 & 3.02 & 37.05 & 25.15 & 35.7 & 60 & 45.44 & 2.39 & 53.7 & 19.86 & 53.66 & 8 & 6.89 & 0.32 & 11.94 & 2.65 & 11.87 \\
\hline 27.5 & 17 & 5.2 & 0.64 & 7.86 & 7.9 & 11.23 & 12 & 9.11 & 0.71 & 15.97 & 5.93 & 16.03 & 4 & 3.47 & 0.24 & 8.96 & 1.97 & 8.84 \\
\hline \multicolumn{19}{|l|}{32.5} \\
\hline \multicolumn{19}{|l|}{37.5} \\
\hline \multicolumn{19}{|l|}{42.5} \\
\hline TOTAL & 312 & 100 & 8.15 & 100 & 70.43 & 100 & 132 & 100 & 4.45 & 100 & 37.01 & 100 & 116 & 100 & 2.68 & 100 & 22.32 & 100 \\
\hline & \multicolumn{6}{|c|}{$\mathrm{Dg}=16 \mathrm{~cm}$} & \multicolumn{6}{|c|}{$\mathrm{Dg}=20.6 \mathrm{~cm}$} & \multicolumn{6}{|c|}{$\mathrm{Dg}=15.3 \mathrm{~cm}$} \\
\hline & \multicolumn{6}{|c|}{$\mathrm{Hg}=11.2 \mathrm{~m}$} & \multicolumn{6}{|c|}{$\mathrm{Hg}=11.8 \mathrm{~m}$} & \multicolumn{6}{|c|}{$\mathrm{Hg}=10.5 \mathrm{~m}$} \\
\hline & \multicolumn{6}{|c|}{$\mathrm{Iv}=1.95 \mathrm{~m} 3 / \mathrm{ha}$} & \multicolumn{6}{|c|}{$\mathrm{Iv}=1.33 \mathrm{~m} 3 / \mathrm{ha}$} & \multicolumn{6}{|c|}{$\mathrm{Iv}=0.85 \mathrm{~m} 3 / \mathrm{ha}$} \\
\hline & \multicolumn{6}{|c|}{ Piv $=0.94 \%$} & \multicolumn{6}{|c|}{ Piv $=1.46 \%$} & \multicolumn{6}{|c|}{ Piv $=2.11 \%$} \\
\hline & \multicolumn{6}{|c|}{ STAND AGE } & & Part & pation & UTUR & TREES & & & & INTEN & ITY $\mathrm{CU}$ & & \\
\hline & & & & 2 age & & & & & By 1 & $42.85^{\circ}$ & & & & & & $37.66 \%$ & & \\
\hline & & $\mathrm{ST}$ & rUS A & ER CU & TING & & & & By & $54.60^{\circ}$ & & & & & By & $=32.88 \%$ & & \\
\hline & & 192 & 5 & & 48.11 & & & & By I & 52.54 & & & & & By I & $=31.69 \%$ & & \\
\hline & & & & & & & & & By $P$ & $=68.20^{\circ}$ & & & & & By $P$ & $=42.05^{\circ}$ & & \\
\hline
\end{tabular}


Acta Agriculturae Serbica, Vol. XX, 39 (2015); 29 - 39

Explanation for the tables: $\mathrm{N}$-number of trees

G-Basal (surface cross-sections of trees)

V- Volume

Dg -average diameter

Hg-Medium-average height

Iv-increment volume

Piv-percentage volume increment

Note: These are two experimental field extremes i.e. the best and worst plantations presented in order to recognize and determine differences between plantations with care practices and those without them.

Explanation:

$\mathrm{N}$ - the number of trees per hectare.

G- Basal (surface river basin sections of trees) per hectare.

V- volume per hectare.

Dg- average diameter per ha.

$\mathrm{Hg}$-Medium-average height per hectare.

Iv -Current increment per ha.

$\mathrm{Pi}$-Percent volume increment per ha.

The values in the tables are given per hectare.

Tables show comparison between plantations cultivated on land i.e. on a eutric brown soil with good properties and plantations without care practices (no cropping-thinning) cultivated on the worst land i.e. shallow humus silicate land.

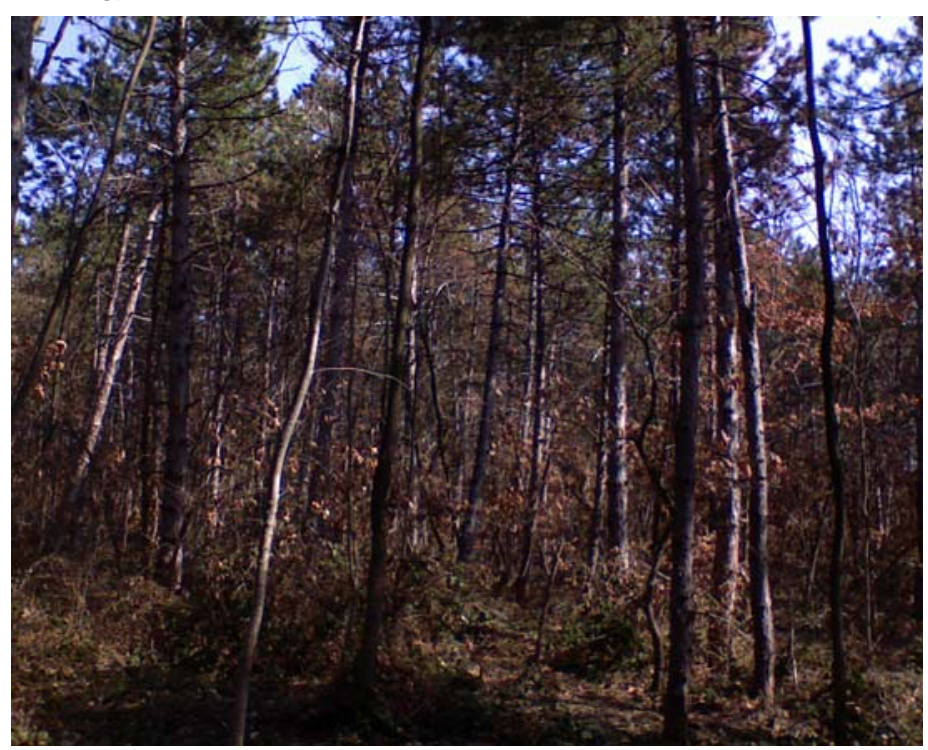

Figure.1. Plantation without care practices on poor soil. 
Acta Agriculturae Serbica, Vol. XX, 39 (2015); 29 - 39

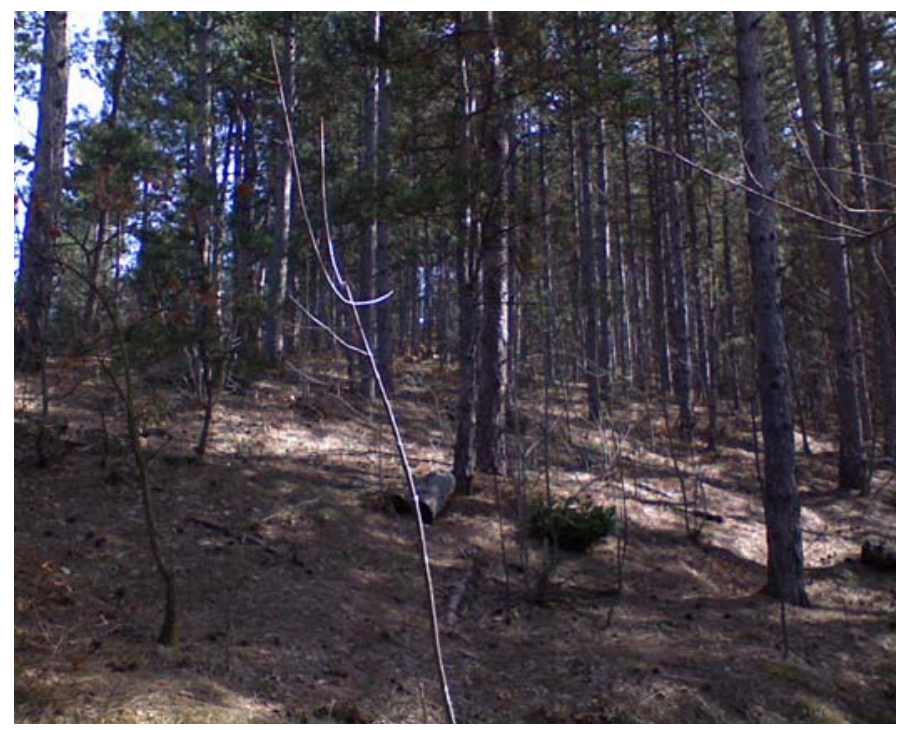

Figure.2. Plantation with care practices on good land.

The examples above show two extremes i.e. plantation on good soil with care practices and plantation without care practices on poor soil.

Black pine plantations in this territory require care practices to prevent their stagnation and ensure their maximum performance in terms of development and growth.

Care practices proposed for experimental field I: low-thinning of medium intensity, thinning of 5-8 years. The number of trees $\mathrm{N}-33 \%$ by the root, G$30.36 \%$, by volume V $30.42 \%$ and increment $\mathrm{Jv} 31.7 \%$.

Care practices proposed for experimental field II: high-spacing, medium intensity - selecting the best trees, the trees of the future, as the bearers of future development, and thinning intensity of 8-10 years. The number of trees N$34.83 \%$, per journal entry G-33.12\%, by volume, V-33.14\% and increment of $41.66 \%$.

Care practices proposed for experimental field III: selective thinning of moderate severity, with the selection of future trees, with thinning intensity of 58 years.

Care practices proposed for experimental field IV: selective thinning of high severity, selecting a certain number of trees in the future, with thinning intensity of 8-10 years. The number of trees N-32.38\%, per root entry G $28.39 \%$, by volume V $28.41 \%$ and increment Iv-36.25\%.

Care practices proposed for experimental field $\mathbf{V}$ : low thinning, removal of all phenotypically poor trees, with thinning intensity of 5-8 years of age. The selection by $\mathrm{N}-37.66 \%$, per root entry G-32.88\% by volume of $\mathrm{V}-31.69 \%$, and the current volume increment Iv-31.84\%. 
Acta Agriculturae Serbica, Vol. XX, 39 (2015); 29 - 39

\section{Conclusion}

Black pine i.e. black pine plantations in this region have shown a certain extent of justification for the introduction of black pine to a better habitat. Height, diameter and weight have significantly higher values in tended plantations than in plantations without care practices. The comparison of values reveals differences between plantations with and without care practices. Diameter $(\mathrm{Dg})$ in plantations with and without care practices is $31.1 \mathrm{~cm}$ and $16 \mathrm{~cm}$, respectively. The average height $(\mathrm{Hg})$ is $18.7 \mathrm{~m}$ in tended plantations and $11.2 \mathrm{~m}$ in plantations without care practices. Annual increment (IV) is $3.87 \mathrm{~m} 3 /$ ha in plantations with care practices, and $1.95 \mathrm{~m} 3$ / ha in untended plantations. Similar results were obtained for the volume increment percentage (VIP). These are highly important and visible indicators that show the necessity of using care practices in pine crops. Differences are also observed when comparing the tabular values for the trees of the future. Future trees are trees that are the best in one-bed culture, and will remain as such until the end of rotation.

\section{References}

A n t i ć. M., J o v i ć. N., A v d a 1 o v i ć. V.,(1998): Pedologija, Udžbenik, Naučna knjiga, Beograd, pp. 55-59

B a n k o v i ć. S., (1995) Metodi i tehnika, naučnoistraživačkog rada-UdžbenikBeograd, pp. 62-70.

C e d r o. A., (2006). Comparative Dendroclimatological Studies of the Impact of Temperature and Rainfall on Pinus nigra Arnold and Pinus sylvestris in Northwestern Poland. Baltic Forestry, Vol. 12 (1): 110-116.

J o v a n o v i ć. S., (1988), Gajenje šuma-Udžbenik, Naučna knjiga, Beograd.- pp. 200230

M y e r s, J.,P., (2002), From Silent Spring to Scientific Revolution. San Francisco Medicine 75: 24-28

$\mathrm{N}$ a ci onalana invetura š u ma, (2012).Beograd., p: 84-87

R a k o nj ac. Lj., E $r$ t e k I n. K., F u r t u 1 a. R., (2000), Časopis Šumarstvo,Istraživanje prijema šumskih kultura crnog bora, na Pešterskoj visoravni, Beograd .p 40-45.

T o m a n i ć. L., (1968), Crni bor na Goču, struktura, razvitak, produktivnost, i način gazdovanja, Magistarski rad, Beograd . p 55-60.

T o m i ć. Z., (2004), Fitocenolgija udžbenik,Naučna knjiga, Beograd. p 35-40,

$\mathrm{S} \mathrm{t}$ a $\mathrm{m}$ e $\mathrm{n} \mathrm{k}$ o v i ć. V., V u č k o v i ć. M., -(1988) - Prirast i proizvodnost stabala šumskih sastojina-Udžbenik, Šumarski fakultet-Beograd p:192-199.

M i r k o v i ć. Č., (1972) -Dendrometrija-Udžbenik-Šumarski fakultet p: 87-94, Beogarad.

A s s m a n n. E., (1966) -Waldertragskunde. Munchen-Bonn-Wien p:105-108. 
Acta Agriculturae Serbica, Vol. XX, 39 (2015); 29 - 39

\title{
VISINSKE KRIVE KAO NOV ASPEKT KULTURA CRNOG BORA NA PODRUČJU ŠUMADIJE
}

\author{
Severin Šikanja \\ Fakultet za primenjenu ekologiju Futura,Univerzitet Singidunum
}

\section{Rezime}

Analizirani su i proučavani svi ekološki faktori: biotički i abiotički u kulturama crnog bora na području Šumadije. Istraživane kulture crnog bora u okviru 5 oglednih polja starosti 30, 40 i 55-60 godina nalaze se na:

1) dobrim staništima

2) srednjim $i$

3) lošim staništima, da bi se videlo kako se iste starosti kultura ponašaju na različitim staništima.

Urađena su sva dendrometrijska merenja, prsni prečnik, visina i obračunata zapremina stabala. Urađena je analiza stabla i kompletan obračun prirasta. Prikazana je kompletna struktura sastojina-kultura, debljinska, visinska, po temeljnici i zapreminska struktura.

Urađene su visinske krive kao nov značajan pokazatelj. Na kraju, donet je zaključak i mere nege za svako ogledno polje, kao i predlog gajenja u budućnosti.

Ključne reči: crni bor, kulture, Šumadija,ekološke karakteristike. 